\title{
Pemanfaatan Limbah Kolam Lele dan Bacillus sp untuk meningkatkan pertumbuhan dan hasil Padi (Oryza sativa)
}

\author{
Tri Rahayuningsih ${ }^{1}$, Susantriana Dewi ${ }^{2}$ \\ ${ }^{1}$ Fakultas Pertanian, Universitas Merdeka Ponorogo, Jl. Pacar 30, Ponorogo, 63418 \\ E-mail: trihayunngsih10@yahoo.co.id \\ ${ }^{2}$ Fakultas Ekonomi, Universitas Merdeka Ponorogo, Jl. Pacar 30, Ponorogo, 63418 \\ E-mail: susanardino@gmail.com
}

\begin{abstract}
Catfish pond waste has a high content of organic matter and nutrients (nitrogen) which can be used as a source of nutrition for rice plants, but on the other hand it also contains ammonia which can interfere with rice growth. Therefore, research is needed to reduce the negative effects of using catfish pond waste. in rice cultivation, by utilizing Bacillus sp. The purpose of this research is to obtain information about how to use catfish pond waste for rice cultivation, by utilizing the Bacillus sp. Bacteria. Bacillus sp is thought to increase nutrient availability for rice. The method to be carried out in this study used a randomized block design with treatment A0 (control), A1 (Bacillus sp), A2 (catfish waste), A3 (catfish waste + Bacillus sp), A4 (Urea fertilizer). The results of this study found that pond waste and Bacillus sp. Affected the growth and yield of rice. The highest results were obtained in the combination treatment of pond waste with Bacillus sp.
\end{abstract}

Keywords—: Bacillus sp; catfish pond waste; organic rice.

\section{PENDAhULUAN}

Pada sistem budidaya padi sawah memerlukan biaya tinggi khususnya untuk pembelian pupuk anorganik. Alternatif menekan biaya produksi adalah pemakaian bahan yang ada disekitar lahan untuk menggantikan pupuk anorganik. Pupuk anorganik dapat digantikan dengan pupuk organik yang memiliki kandungan hara tinggi. Salah satu bahan organik yang dapat digunakan untuk sumber nutrisi adalah limbah kolam lele, karena limbah kolam lele mengandung $\mathrm{N}$ dalam jumlah yang tinggi yang berasal dari sisa pelet dan feces ikan. Pelet ikan mengandung $30 \%$ protein dan feces ikan mengandung bahan organik yang dapat diuraiakan menjadi senyawa N. Sisa pellet dapat digunakan sebagai sumber nutrisi tanaman (Effendi et al,2015).

Permasalahan pengunaan limbah kolam lele pada lahan sawah yaitu limbah kolam lele mengandung amoniak yang tidak dapat diserap oleh tanaman, selain itu juga dapat menganggu aktivitas mikroba tanah yang menguntungkan bagi tanaman. Amoniak merupakan gas yang dapat bersifat toksik bagi mikroba tanah. Kadar Amoniak tinggi di air kolam tinggi berasal dari penguraian pelet ikan dan feses ikan. Namun demikian amoniak dapat diubah menjadi nitrat dengan adanya bakteri Bacillus sp. Bacillus sp dapat mengurangi kadar amoniak pada limbah kolam udang sebesar 90\% (Itjamilah et al, 2009)

Tujuan khusus penelitian ini yaitu untuk mengkaji penggunaan Bacillus sp sebagai bioremediasi limbah kolam lele sehingga dapat dimanfaatkan untuk budidaya padi. Berdasarkan penelitian Tinendung et.al. (2014) bahwa pemanfaatan Bacillus sp+ limbah cair tahu dapat meningkatkan berat gabah kering padi dari $28 \mathrm{~g} /$ tanaman menjadi $36 \mathrm{~g} / \mathrm{tanaman}$.

Penelitian ini dapat digunakan sebagai acuan pemanfataan limbah kolam lele dalam mendukung budidaya padi dan penghematan biaya produksi padi. Penghematan biaya dapat dilakukan mengurangi biaya untuk pembelian pupuk anorganik, yang diganti dengan limbah kolam lele dan Bacillus sp, sehingga pendapatan petani dapat ditingkatkan.

\section{METODE PENELITIAN}

Penelitian dilakukan di lahan berkapur di desa Sampung kecamatan Sampung kabupaten Ponorogo. Penelitian ini dilakukan dengan 3 tahap yaitu pertama perbanyakan bakteri activator. Kedua pengurangan amoniak oleh Bacillus sp. Ketiga uji hasil fermentasi pada tanaman padi kondisi lapangan.

\section{A. Perbanyak bakteri Bacillus sp}

Bakteri yang akan digunakan dalam penelitian ini adalah bakteri hasil isolasi dari limbah pabrik kayu putih dan telah diperbanyak di laboratorium Fakultas Pertanian Universitas Merdeka Ponorogo. Bakteri ini mampu hidup pada media air yang mengandung bahan organik. Perbanyakan bakteri dilakukan dengan menggunakan media cair yang mengandung gula. Jumlah Bacillus sp yang digunakan memiliki jumlah koloni $1.57 \times 10^{6}$. 
Website : http://agritek.unmermadiun.ac.id/index.php/agritek

\section{B. Pencampuran Bacillus sp dengan limbah kolam}

Limbah kolam lele yang akan digunakan dalam penelitian ini diperoleh dari sekitar lahan. Limbah kolam lele yang digunakan ada yang difermentasi dengan Bacillus sp dan tanpa penambahan Bacillus sp. Fermentasi dilakukan selama 2 x 24 jam dan diberi sirkulasi udara.

\section{Percobaan di lahan}

Penelitian dilakukan dengan rancangan acak kelompok kelompokdengan 3 ulangan.Perlakuannya yaitu : A0 = control, $\mathrm{A} 1=$ Bacillus sp, A2 = Limbah kolam lele, A3 = Limbah kolam lele + Bacillus $s p$, A4 = pupuk Urea

Lahan diolah dan dibuat petak sejumlah 15 petak dengan ukuran 4 x $6 \mathrm{~m}$. Jarak antar petak dibuat $60 \mathrm{~cm}$. Setiap petak di airi limbah sesuai perlakuan. Kemudian lahan ditanami padi dengan jarak tanam $30 \times 25 \mathrm{~cm}$. Tanaman dilakukan perawatan pengendalian hama dan penyakit. Panen dilakukan pada umur 110 hari setelah tanam. Tanaman sampel dibersihkan kemudian dilakukan pengamatan tinggi tanaman, , jumlah anakan, berat total brangkasan, berat kering brangkasan, berat biji.

Analisis data dilakukan dengan menggunakan ANOVA satu arah dengan program SPSS 16. Apabila terdapat perbedaan yang signifikan maka analisa dilanjutkan dengan uji LSD untuk mencari perbedaan antar perlakuan.

\section{III.HASIL DAN PEMBAHASAN}

Perlakuan limbah kolam lele dan Bacillus sp mempengaruhi tinggi tanaman padi (Gambar 1). Aplikasi Bacillus sp baik secara sendiri maupun yang dikombinasikan dengan limbah kolam lele dapat meningkatkan tinggi tanaman bila dibanding dengan tanpa pemupukan. Pupuk urea yang diaplikasikan pada padi memiliki tinggi tanaman dapat digantikan dengan aplikasi Bacillus sp atau limbah kolam lele yang dikombinasikan dengan Bacillus sp. Aplikasi Limbah kolam lele akan lebih baik dikombinasikan dengan Bacillus sp. Bacillus sp merupakan bakteri yang dapat menguraikan amoniak dan diubah menjadi amonium atau nitrat yang dapat diserap oleh tanaman. Hal ini terbukti bahwa pemberian Bacillus sp mampu meningkatkan tinggi tanaman padi. Bacillus $s p$ merupakan bakteri heterotrof yang dapat meningkatkan ketersedian nitrogen pada lahan sawah (Michaud et al., 2006). Limbah kolam lele dapat digunakan untuk mengantikan pupuk urea dalam meningkatkan tinggi tanaman padi.

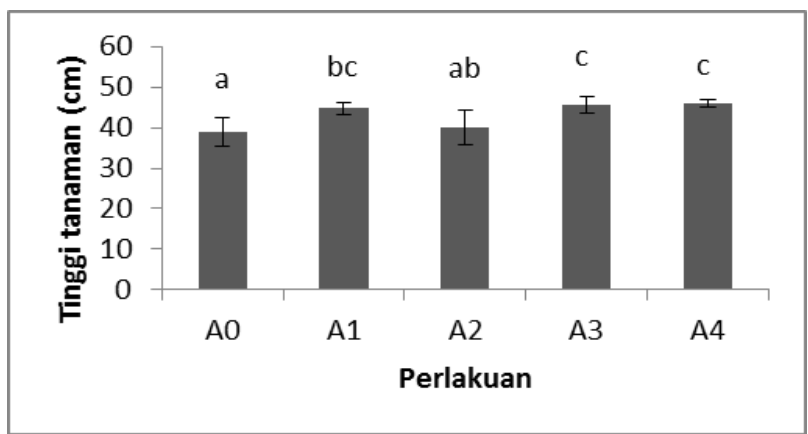

Gambar 1. Tinggi tanaman (A0 : kontrol, A1 : Bacillus sp, A2 : Limbah kolam lele, A3: Limbah kolam lele + Bacillus sp, A4 : Urea

Jumlah anakan padi yang dipupuk urea, limbah kolam dan Bacillus sp lebih tinggi dibanding dengan tanpa pupuk (Gambar 2). Limbah kolam lele merupakan sumber bahan organik yang dapat digunakan sebagai bahan pupuk . Bahan organik yang terkandung dalam air kolam berasal dari feces ikan lele dan sisa pakan lele. Pakan lele banyak mengandung protein yang berguna untuk mempercepat pertumbuhan ikan. Protein merupakan senyawa yang banyak mngandung N, sehingga bila didekomposisi akan melepaskan senyawa $\mathrm{N}$ yang dapat diserap oleh tanaman. Hal sejalan dengan pemanfaatan limbah kolam ikan untuk tanaman kangkung. Limbah kolam dapat meningkatkan tananaman kangkung (Effendi et al., 2015)

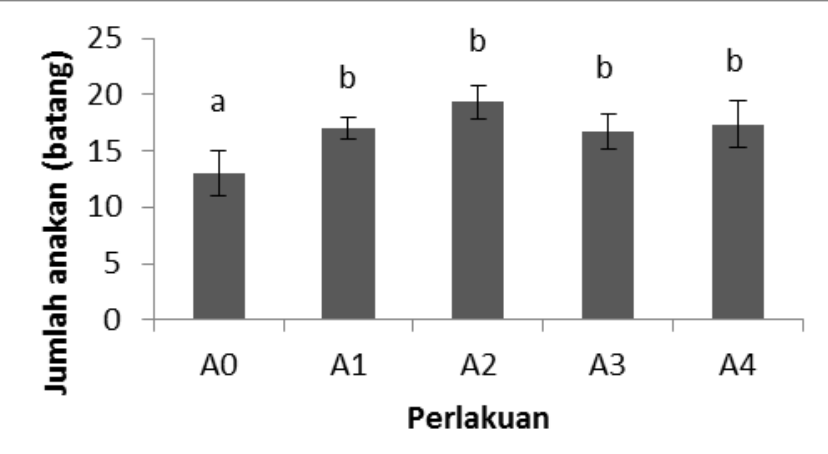

Gambar 2. Jumlah anakan (A0 : kontrol, A1 : Bacillus sp, A2 : Limbah kolam lele, A3: Limbah kolam lele + Bacillus sp, A4 : Urea 
Website : http://agritek.unmermadiun.ac.id/index.php/agritek

Aplikasi Bacillus sp dan limbah kolam lele secara tunggal dapat meningkatkan jumlah daun dibanding dengan tanpa pemupukan (Gambar 3). Bacillus sp yang diaplikasikan secara tunggal memiliki jumlah daun yang tidak berbeda nyata dengan Bacillus $s p$ yang dikombinasikan dengan limbah kolam lele. Hal ini berarti Bacillus $s p$ lebih baik diaplikasikan secara tunggal daripada dikombinasikan dengan limbah kolam lele. Hal ini sejalan dengan pemanfaatan Bacillus sp pada tanaman padi. Bacilus sp dapat meningkatkan tanaman produksi padi (Tinendung et al,2014). Pemberian limbah lele dapat meningkatkan kandungan bahan organik tanah yang akan mempengaruhi $\mathrm{pH}$ tanah (Agustiyani, et al., 2004)

Bacillus $s p$ merupakan bakeri heterotrof yang mampu mengubah senyawa organik menjadi tersedia bagi tanaman. Aplikasi Bacillus sp dalam tanah akan memacu perombakan bahan organik yang merupakan bahan makanan yang baik bagi bakteri heterotrof yang lainnnya. Bacillus sp dapat mengeluarkan enzim yang mampu melepaskan unsur hara yang terikat oleh tanah (Itjamilah, et al., 2009). Selain itu bakteri juga dapat meningkatkan kualitas air sawah sehingga dapat meningkatkan kesehatan tanah (Herdianti et al., 2015)

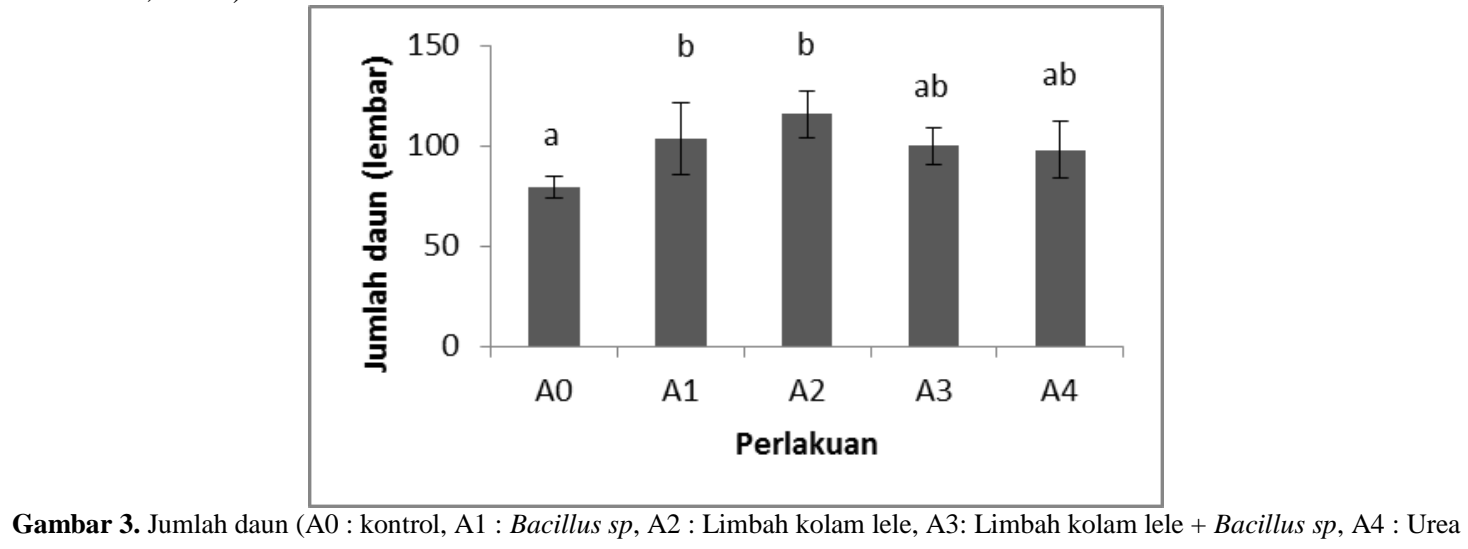

Limbah kolam lele dan Bacillus sp mempengaruhi berat kering dan berat basah brangkasan padi. Berat kering brangkasan tertinggi pada penggunaan pupuk urea dan terendah pada peralakuan kontrol. Perlakuan kombinasi kolam lele dengan Bacillus sp belum dapat meningkatkan berat kering brangkasan padi dibanding dengan limbah kolam lele dan Bacillus sp secara tunggal, tetapi bila dibanding dengan pupuk urea memiliki berat kering lebih rendah.

Berat basah brangkasan padi pada penggunaan limbah kolam lele, Bacillus sp dan urea secara tunggal lebih tinggi dibanding dengan kontrol. Berat basah brangkasan tertinggi pada penggunaan pupuk urea dan terendah pada perlakuan kontrol. Perlakuan kombinasi kolam lele dengan Bacillus sp belum dapat meningkatkan berat basah brangkasan padi dibanding dengan limbah kolam lele dan bacillus sp secara tunggal, tetapi bila dibanding dengan pupuk urea memiliki berat basah lebih rendah.

\begin{tabular}{ccc}
\multicolumn{3}{c}{ Tabel 1. Rata-rata berat kering dan berat basah brangkasan padi } \\
\hline Perlakuan & Berat kering brangkasan & Berat basah brangkasan \\
\hline A0 & $30,49 \pm 1,29 \mathrm{a}$ & $61,79 \pm 3,70 \mathrm{a}$ \\
$\mathrm{A} 1$ & $40,28 \pm 8,84 \mathrm{ab}$ & $86,58 \pm 13,50 \mathrm{~b}$ \\
$\mathrm{~A} 2$ & $41,98 \pm 4,02 \mathrm{~b}$ & $91,51 \pm 9,65 \mathrm{bc}$ \\
$\mathrm{A} 3$ & $35,17 \pm 0,23 \mathrm{ab}$ & $72,77 \pm 12,32 \mathrm{ab}$ \\
A4 & $56,86 \pm 5,63 \mathrm{c}$ & $109,27 \pm 12,23 \mathrm{c}$ \\
\hline
\end{tabular}

Ket : Angka yang didampingi huruf yang sama pada kolom yang sama tidak berbeda atas uji BNT $(0,05)$

Berat biji padi perlakuan kontrol lebih rendah dibanding dengan perlakuan yang lainnya. Perlakuan pupuk urea memiliki berat biji padi lebih tinggi dibanding dengan perlakuan limbah lele dan Bacillu sps yang diberikan secara tunggal. Kombinasi limbah lele dengan Bacillus $s p$ dapat meningkatkan berat biji padi dibanding dengan limbah lele dan Bacillus sp yang diberikan secara tunggal.

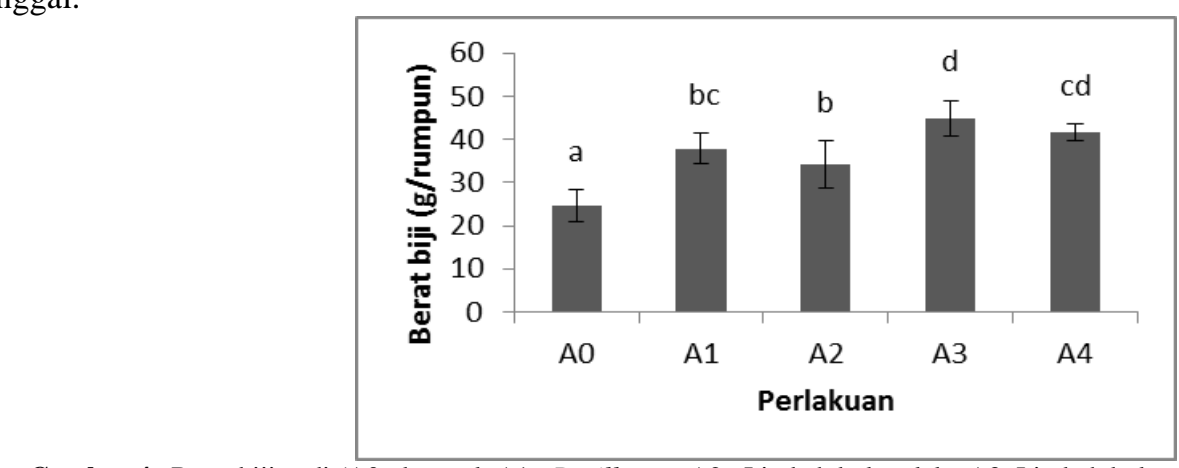

Gambar 4. Berat biji padi (A0 : kontrol, A1 : Bacillus sp, A2 : Limbah kolam lele, A3: Limbah kolam lele + Bacillus sp, A4 : Urea 
Website : http://agritek.unmermadiun.ac.id/index.php/agritek

Hasil korelasi antar parameter pengamatan didapatkan bahwa berat biji padi berkorelasi positif dengan tinggi tanaman $(\mathrm{r}=$ $0,536 *)$ dan jumlah anakan $(\mathrm{r}=0,602 *)$. Semakin banyak jumlah anakan maka akan menghasilkan jumlah biji lebih banyak. Jumlah anakan berkorelasi positif dengan jumlah daun $(\mathrm{r}=0,714 * *)$. Hal ini sejalan dengan peneliian Budi e al (2018) yang menyatakan bahwa berat kering giling gabah berkorelasi positif dengan jumlah anakan dan tinggi tanaman. Tanaman yang memiliki tinggi tanaman dan jumlah anakan lebih tinggi akan menghasilkan fotosintat lebih banyak sehingga berdampak pada peningkatan berat biji padi (Mujiyo et al., 2015). Berat basah brangkasan berkorelasi positif dengan berat kering brangkasan ( $r$ $=0,864 * *)$ dan jumlah anakan $(r=.0,595 *)$.

Tabel 2. Hasil korelasi antar parameter pengamatan

\begin{tabular}{|c|c|c|c|c|c|c|}
\hline & $\begin{array}{l}\text { Tinggi } \\
\text { tanaman }\end{array}$ & Jumlah anakan & $\begin{array}{c}\text { Jumlah } \\
\text { daun }\end{array}$ & $\begin{array}{c}\text { Berat } \\
\text { biji }\end{array}$ & $\begin{array}{c}\text { Berat } \\
\text { kering } \\
\text { brangkasan }\end{array}$ & $\begin{array}{l}\text { Berat basah } \\
\text { brangkasan }\end{array}$ \\
\hline $\begin{array}{l}\text { Tinggi } \\
\text { tanaman }\end{array}$ & 1 & & & & & \\
\hline $\begin{array}{l}\text { Jumlah } \\
\text { anakan }\end{array}$ & .132 & 1 & & & & \\
\hline $\begin{array}{l}\text { Jumlah } \\
\text { daun }\end{array}$ & .129 & $.714^{* *}$ & 1 & & & \\
\hline Berat biji & $.536^{*}$ & $.602^{*}$ & .374 & 1 & & \\
\hline $\begin{array}{l}\text { Berat } \\
\text { kering } \\
\text { brangkasan }\end{array}$ & .424 & .433 & .341 & .420 & 1 & \\
\hline $\begin{array}{l}\text { Berat } \\
\text { basah } \\
\text { brangkasan }\end{array}$ & .426 & $.595^{*}$ & .494 & .387 & $.864^{* * *}$ & \\
\hline
\end{tabular}

\section{IV.KESIMPULAN}

Limbah kolam dan Bacillus sp mempengaruhi perumbuhan dan hasil padi. Limbah kolam mengakibakan jumlah daun dan jumlah anakan teringgi. Kombinasi limbah dengan Bacillus sp dapat meningkat hasil padi dibanding limbah dan Bacillus $s p$ secara tunggal. Berat biji padi berkorelasi positif dengan tinggi tanaman dan jumlah anakan. Penggunaan limbah kolam lele yang dikombinasikan dengan Bacillus $s p$ dapat menggantikan peran pupuk urea

\section{DAFTAR PUSTAKA}

Agustiyani D. Imamuddin H, Faridah EN, Oedjijono, 2004. Pengaruh pH dan Substrat Organik Terhadap Pertumbuhan danAktivitas Bakteri Pengoksidasi Amonia.Biodiversitas 5 (2) : 43-47

Budi LS, Rahayu S, dan Nurwantara MP. 2018. Pengaruh Dosis Dan Interval Pupuk Pelengkap Cair Terhadap Daya Hasil Tanaman Padi (Oryza Sativa. L) Model Jajar Legowo.AGRI-TEK 19 (2) : 64 -69

Effendi H, Utomo BA,Darmawangsa GM, Karo REK, 2015.Fitoremediasi limbah budidaya ikan lele (Clarias sp.) dengankangkung (Ipomoea aquatica) dan pakcoy (Brassica rapa chinensis)dalam sistem resirkulasi. Ecolab9 (2) : 47 - 104

Herdianti L, Soewardi K, Hariyadi S. 2015. Efektivitas Penggunaan Bakteri Untuk Perbaikan Kualitas Air Media BudiDaya Udang Vaname (Litopenaeus vannamei) Super Intensif .Jurnal Ilmu Pertanian Indonesia (JIPI) 20 (3): 265-271

Itjamilah, Meryandini A, Rusmana I, Suwanto A,and Mubarik NR, 2009. Activity of Proteolytic and Amylolytic Enzymes from Bacillus spp.Isolated from Shrimp Ponds.Microbiology 2 (3) : 67-71

Michaud L, Blancheton JP, Bruni V, Piedrahita R, 2006. Effect of particulate organik carbon on heterotrophic bacterialpopulations and nitrification efficiency in biological filters.Aquacultural Engineering34:224-233

Mujiyo, Bambang Hendro Sunarminto BH, Eko Hanudin E dan Jaka Widada J,2015. Pertumbuhan Dan Hasil Padi Sawah Organik Dengan Menggunakan Pupuk Kandang Sapi Dan Azolla. Caraka Tani-Journal of Sustainable Agriculture, Vol. 30 No. 2, :. 69-75

Tinendung R, Puspita F, Yoseva S, 2014. Uji formulasi bacillus sp. sebagai pemacu pertumbuhan tanaman padi sawah (oryza sativa 1.).JOM Faperta Vol 1.No. 2 . 